\title{
Determination of Nicotine in Low-Nicotine Tobacco*
}

\author{
by L. A. Lyerly and G. H. Greene \\ Research Department, R. J. Reynolds Tobacco Company, Winston-Salem, North Carolina, U.S.A.
}

\section{INTRODUCTION}

Most methods of analysis for nicotine in tobacco which have been previously reported were designed for normal levels $(1-3 \%)$ of nicotine. Some of the methods involve other alkaloids, and the results are expressed in terms of nicotine. For determination of very low nicotine levels $(<0.20 \%)$, a gas chromatographic method specific for nicotine is presented. This method is rapid, accurate, and reproducible. It utilizes modifications of GC conditions described by Mumpower and Kiefer $(x)$ for determining nicotine in smoke. The use of n-hexadecane as an internal standard was also suggested by Mumpower (2). GC calibration has been simplified by use of nicotine salicylate, thereby avoiding the need to have freshly distilled nicotine available at all times. Data are presented to show the applicability of the method over the range investigated, $0.05 \%-3.0 \%$ nicotine.

\section{EXPERIMENTAL}

\section{Apparatus}

Gas chromatograph equipped with flame ionization detector.

\section{Materials}

A - Extracting solution, contains $0.5 \mathrm{ml} \mathrm{n}$-hexadecane in 4 liters of chloroform.

$\mathrm{B}-$ Nicotine standard, stock solution. Dissolve $0.1851 \mathrm{~g}$ nicotine salicylate in water and dilute to $100 \mathrm{ml}$ (contains the equivalent of $1.0 \mathrm{mg} / \mathrm{ml}$ nicotine).

C $-10 \%$ sodium hydroxide.

\section{Procedure}

Sample Preparation: Weigh accurately $1 \mathrm{~g}$ of tobacco (low-nicotine variety) into a $125 \mathrm{ml}$ glass-stoppered Erlenmeyer flask. Wet with 5-10 ml of water. Pipet $25 \mathrm{ml}$ of extracting solution into the flask. Add about $5 \mathrm{ml}$ of $10 \% \mathrm{NaOH}$ and extract by agitating on a shaking machine for 10 minutes. Filter sample through

\footnotetext{
- Presented in part at the 29th Tobacco Chemists' Research Conference, College Park, Maryland, October 8-10, 1975.
}

a funnel containing a small amount of glass wool into a $60 \mathrm{ml}$ separatory funnel. Collect a sample of the thloroform layer (bottom) for GC analysis.

Standard Preparation: Pipet $1 \mathrm{ml}$ of nicotine stock solution into a $125 \mathrm{ml}$ Erlenmeyer flask and treat as in Sample Preparation. Collect most of the dhloroform layer, stopper, and store for use until new extracting solution needs be prepared.

Chromatographic Conditions and Analysis:

Column: $3 \mathrm{ft} . X_{1} / 8$ in. SS packed with $10 \%$ Castorwax and $3 \% \mathrm{KOH}$ on Chromosorb $W(60 / 80$ mesh).

Column temperature: $160^{\circ} \mathrm{C}$.

Detector temperature: $270^{\circ} \mathrm{C}$.

Injector temperature: $260^{\circ} \mathrm{C}$.

Carrier gas: Helium at $50 \mathrm{ml} / \mathrm{min}$.

Air: $350 \mathrm{ml} / \mathrm{min}$.

Hydrogen: $30 \mathrm{ml} / \mathrm{min}$.

Presaturation of the GC column with several injections of a tobacco extract will result in higher degree of reproducibility. Inject $2 \mu \mathrm{l}$ of nicotine standard into the gas chromatograph and determine the peak height or area ratio nicotine:hexadecane. Inject $2 \mu l$ of a diloroform extract of tobacco and determine the nicotine:hexadecane ratio. By direct comparison, the $\%$ nicotine may be calculated.

\section{RESULTS AND DISCUSSION}

A typical dhromatogram of a tobacco extract is shown in Figure 1. Figure 2 shows a dhromatogram of an extract of tobacco high in nornicotine. No other alkaloid was detectable in the nicotine peak with GCmass spectrometric techniques.

Table I compares results obtained by the GC method described, the German picrate method (3), and a cyanogen bromide method modified from that of Harvey et al. (4). The GC and picrate methods agree quite well. The cyanogen bromide method, while reliable in the normal concentration ranges, appears to suffer from background interference at the low range.

Table 2 shows the reproducibility of the GC method on replicate tobacco samples taken from the same container. The analysis was carried out on cut tobacco with the results corrected for $15.26 \%$ moisture, 
Table 1. Comparison of GC, plcrate, and cyanogen bromide methods for low-nicotine tobacco.

\begin{tabular}{r|cccc}
\hline Sample & \multicolumn{3}{|c}{$\begin{array}{c}\text { \% Nicotine } \\
\text { Picrate (3) }\end{array}$} & CNBr (4) \\
\hline 1 & GC & Picrate & 0.26 \\
2 & 0.13 & 0.13 & 0.21 \\
3 & 0.11 & 0.11 & 0.25 \\
4 & 0.09 & 0.10 & 0.21 \\
5 & 0.09 & 0.08 & 0.28 \\
6 & 0.18 & 0.17 & 0.25 \\
7 & 0.09 & 0.12 & 0.34 \\
8 & 0.18 & 0.17 & 0.20 \\
9 & 0.07 & 0.09 & 0.18 \\
10 & 0.06 & 0.11 & 0.20 \\
11 & 0.11 & 0.11 & 0.20 \\
12 & 0.12 & 0.13 & 0.16 \\
13 & 0.08 & 0.09 & 0.22 \\
14 & 0.08 & 0.10 & 0.33 \\
15 & 0.08 & 0.10 & 0.23 \\
\hline
\end{tabular}

Samples 1 to 10 weighed $1 \mathrm{~g}, 11$ to 13 weighed 2,3 and $4 \mathrm{~g}$, respectively.

Table 3 compares results obtained with a variety of methods applied to different tobacco types with various nicotine levels. As previously illustrated, the GC method agrees best with the picrate method. As expected, the silicotungstic acid method gives higher results because of reaction of the silicotungstic acid with other alkaloids. The picric acid method involves

Figure 1. Typical chromatogram of a tobacco extract.

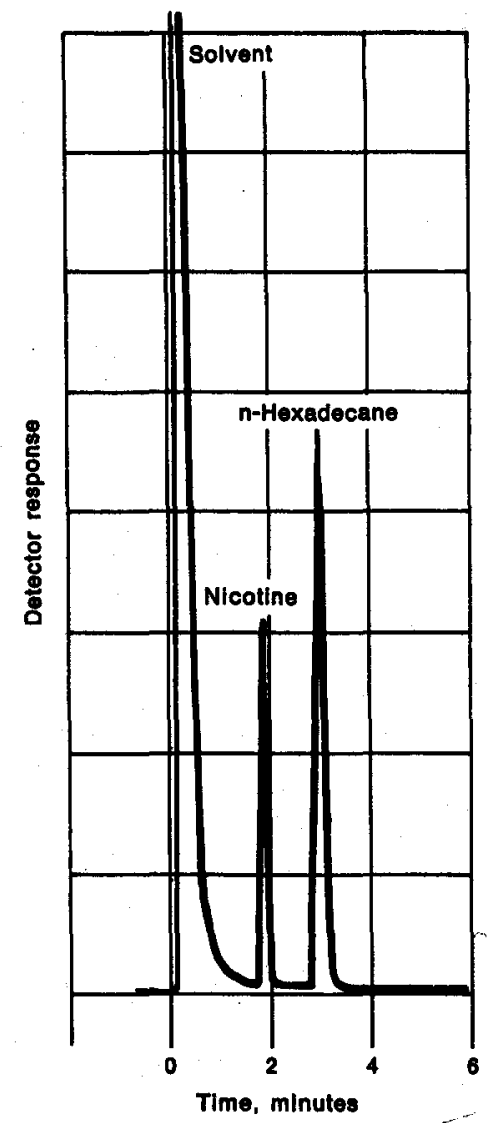

Table 2. Reproduclbility of GC nicotine in cut tobacco samples from same container.

\begin{tabular}{c|c}
\hline Sample & $\begin{array}{c}\text { \% Nicotine } \\
\text { (corrected for moisture) }\end{array}$ \\
\hline 1 & 0.17 \\
2 & 0.17 \\
4 & 0.18 \\
5 & 0.17 \\
6 & 0.16 \\
7 & 0.17 \\
8 & 0.15 \\
9 & 0.17 \\
10 & 0.17 \\
11 & 0.16 \\
12 & 0.16 \\
13 & 0.16 \\
& 0.16 \\
\hline
\end{tabular}

a distillation with $\mathrm{MgO}$ which preferentially results in distillation of nicotine. This method has several disadvantages. It is time consuming, tedious, and generally not suitable for either large numbers of samples or quick results.

\section{SUMMARY}

A gas chromatographic method for the determination of nicotine in low-nicotine tobacco is described. Tobacco samples are extracted with sodium hydroxide

Figure 2. Chromatogram of an extract of a tobacco high in nornicotine.

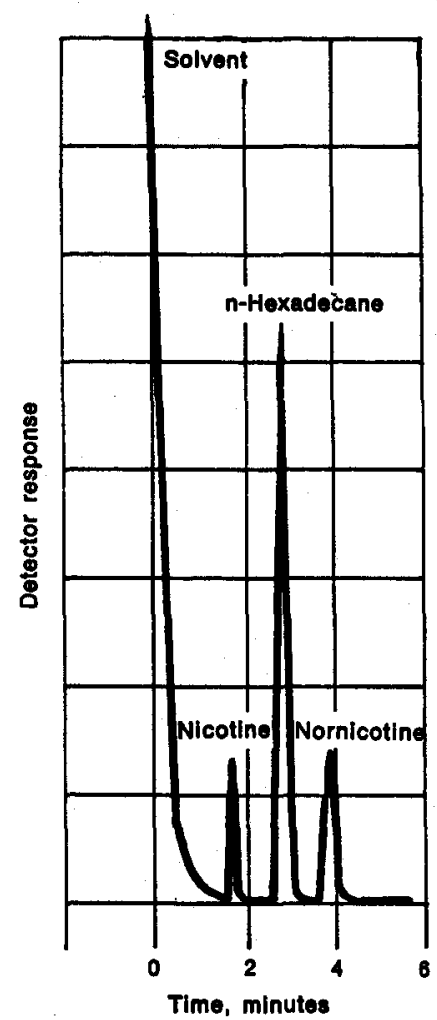


Table 3. Comparison of tobacco* nicotine values by different methods.

\begin{tabular}{|c|c|c|c|c|c|c|}
\hline \multirow{2}{*}{ Tobacco } & \multirow{2}{*}{ GC } & \multirow{2}{*}{ Picrate (3) } & \multirow{2}{*}{$\begin{array}{l}\text { Silicotungstic } \\
\text { acid (5) }\end{array}$} & \multicolumn{2}{|c|}{ Titration (6) } & \multirow{2}{*}{ CNBr (4) } \\
\hline & & & & Total alkaloids & Nicotine & \\
\hline \multirow[t]{3}{*}{ Burley blend } & 2.90 & 2.73 & 3.18 & 3.22 & 2.96 & 2.93 \\
\hline & 2.87 & 2.74 & 3.21 & 3.25 & 2.98 & 2.99 \\
\hline & 2.88 & 2.73 & 3.17 & 3.23 & 2.99 & 2.93 \\
\hline \multirow[t]{3}{*}{ Flue-cured blend } & 1.87 & 1.88 & 2.11 & 2.17 & 2.05 & 1.99 \\
\hline & 1.89 & 1.90 & 2.10 & 2.15 & 2.04 & 1.99 \\
\hline & 1.92 & 1.90 & 2.10 & 2.17 & 2.04 & 1.97 \\
\hline \multirow[t]{3}{*}{ Turkish blend } & 0.69 & 0.73 & 0.85 & 0.96 & 0.90 & 0.82 \\
\hline & 0.69 & 0.69 & 0.83 & 0.95 & 0.89 & 0.83 \\
\hline & 0.68 & 0.71 & 0.85 & 0.96 & 0.90 & 0.81 \\
\hline \multirow[t]{3}{*}{ Commercial blend } & 1.53 & 1.48 & 1.72 & 1.76 & 1.60 & 1.64 \\
\hline & 1.54 & 1.44 & 1.72 & 1.73 & 1.60 & 1.59 \\
\hline & 1.48 & 1.49 & 1.72 & 1.73 & 1.61 & 1.63 \\
\hline \multirow[t]{3}{*}{ Low-nicotine blend } & 0.07 & 0.06 & 0.13 & 0.16 & 0.14 & 0.17 \\
\hline & 0.07 & 0.07 & 0.14 & 0.17 & 0.13 & 0.17 \\
\hline & 0.07 & 0.06 & 0.14 & 0.16 & 0.15 & 0.18 \\
\hline
\end{tabular}

- Tobacco was dried and ground.

solution and chloroform. Nicotine in the chloroform is determined by gas chromatography. The method is applied to different tobacco types of varying nicotine levels and compared with other methods. The method is simple, rapid, and yields reproducible results.

\section{ZUSAMMENFASSUNG}

Es wird eine gaschromatographische Methode zur Bestimmung von Nikotin in Tabaken mit niedrigem Nikotingehalt beschrieben. Die Tabakproben werden mit Natriumhydroxidlösung und Chloroform extrahiert. Das im Chloroform befindliche Nikotin wird durch Gaschromatographie bestimmt. Das Verfahren wird bei verschiedenen Tabakarten mit unterschiedlichen Nikotingehalten angewandt und mit anderen Methoden verglichen. Es ist einfach, schnell und liefert reproduzierbare Ergebnisse.

\section{RESUME}

On décrit une méthode de chromatographie en phase gazeuse pour la détermination de nicotine dans le tabac à faible contenance en nicotine. On procède à l'extraction d'échantillons de tabac à l'aide d'une solution d'hydroxyde de sodium ainsi que de chloroforme. La nicotine contenue dans le chloroforme est déterminée par chromatographie en phase gazeuse. On a appliqué cette méthode à différents types de tabac possédant des concentrations variables de nicotine et comparé cette méthode à d'autres. Cette méthode-ci est simple, rapide et produit des résultats reproductibles.

\section{REFERENCES}

1. Mumpower, R. C., J. E. Kiefer: Tob. Sci. 11 (1967) 144.

2. Mumpower, R. C.: Private communication, 1973.

3. Pfyl, B., and O. Schmitt: Zeitschr. Untersuch. Lebensm. 54 (1927) 60.

4. Harvey, W. R., H. M. Stahr, and W. C. Smith: Tob. Sci. 13 (1969) 13.

5. Manuel Suisse des Denrées Alimentaires, 4th Edition, 1936.

6. Cundiff, R. H., and P. C. Markunas: Anal. Chem. 27 (1955) 1650.

The authors' address:

R. J. Reynolds Tobacco Company, Research Department, Winston-Salem, N.C., 27102, U.S.A. 